\title{
Validation and clinical correlation of triplex CD3, CD8 and FOXP3 IHC of tumor-infiltrating lymphocytes in follicular lymphoma
}

\author{
James Mansfield ${ }^{1 *}$, Christian Slater ${ }^{2}$, Richard Byers ${ }^{2}$ \\ From Society for Immunotherapy of Cancer 29th Annual Meeting \\ National Harbor, MD, USA. 6-9 November 2014
}

It is clear that immune cells play many sometimes conflicting roles in the tumor microenvironment and it would be extremely useful to be able to visualize the distributions of multiple phenotyped immune cells in-situ in solid tumors. However, obtaining phenotypic information about the various cells that play these roles in and around the tumor has been a challenge. Existing methods can either deliver phenotypic information on homogenous samples (e.g., flow cytometry) or morphologic information on single immunomarkers (standard IHC). These limitations can be largely overcome through a multiplexed staining, imaging and analysis methodology using standard clinical FFPE tissue sections. Although multiplex methods have been shown to be particularly useful not much has been presented on the validation of such methods. We present here a validation of the method for CD3, CD8 and FOXP3 in tissue microarray containing triplex follicular lymphoma cores from 40 subjects [ 24 male, 16 female, age 35 to 75 years at diagnosis, median 55 years, 2- 171 months followup]. This involves a sequential multi-marker labeling for 3 antigens and a counterstain; automated multispectral imaging to separate chromogens; and an automated analysis that can quantitate the per-cell marker expression, determine the cellular phenotype, count these cells separately in the tumor compartment and in the stroma and provide high-resolution images of their distributions. The IHC for each marker was optimized in as single-stain IHC and then those specifications used as a part of the triplex stain. The samples were scored using an automated scoring methodology and the results from the triplexed method are compared to analyses done on singly stained sections with excellent correlation ( $R$ greater than 0.9 in

${ }^{1}$ PerkinElmer, Hopkinton, MA, USA

Full list of author information is available at the end of the article all cases), showing that multiplexed staining methods can replicate standard IHC methods while maintaining the inter-distribution and visualization of the markers in a single section.

\section{Authors' details}

${ }^{1}$ PerkinElmer, Hopkinton, MA, USA. ${ }^{2}$ University of Manchester, Manchester, UK.

Published: 6 November 2014

doi:10.1186/2051-1426-2-S3-P261

Cite this article as: Mansfield et al:: Validation and clinical correlation of triplex CD3, CD8 and FOXP3 IHC of tumor-infiltrating lymphocytes in follicular lymphoma. Journal for ImmunoTherapy of Cancer 2014 2(Suppl 3):P261.

Submit your next manuscript to BioMed Central and take full advantage of:

- Convenient online submission

- Thorough peer review

- No space constraints or color figure charges

- Immediate publication on acceptance

- Inclusion in PubMed, CAS, Scopus and Google Scholar

- Research which is freely available for redistribution 